\title{
УПРАВЛІННЯ РОЗВИТКОМ ІННОВАЦІЙНОГО ПОТЕНЦІАЛУ НА ОСНОВІ ТРАНСФЕРУ ТЕХНОЛОГІЙ
}

\author{
УПРАВЛЕНИЕ РАЗВИТИЕМ ИННОВАЦИОННОГО ПОТЕНЦИАЛА НА \\ ОСНОВАНИИ ТРАНСФЕРА ТЕХНОЛОГИЙ
}

\section{A MANAGEMENT DEVELOPMENT OF INNOVATIVE POTENTIAL IS ON BASIS OF TRANSFER OF TECHNOLOGIES}

У статті розглянуто сутність понять «інноваційний потенціал», «оцінка інновачійного потенціалу підприємства». Проаналізовано сильні та слабкі сторони розвитку потенціалу Украӥни. Розглянуто та проаналізовано методи здійснення оцінки інноваційного потенціалу підприємства, сильні та слабкі сторони розвитку потенціалу України. Автором запропоновано комплексний підхід до оцінки інноваційного потенціалу вітчизняного підприємства. Здійснено порівняльний аналіз нормативно-правових особливостей державного регулювання трансферу технологій в Украӥні та США. Виявлено переваги та недоліки законодавчої бази США у сфері передачі технологій. Проаналізовано сучасні тендениіі міжнародного трансферу технологій, особливості вітчизняних законодавчих актів щчодо досліджень і розробок та інновачійної діяльності. Виокремлено проблеми інституційного забезпечення передачі технологій в Украӥні. Сформульовано рекомендачії щэодо вдосконалення вітчизняної законодавчої бази у сфері трансферу технологій.

Ключові слова: інновації; інноваційний потенціал підприємства; трансфер технологій.

В статье рассмотрено сущность понятий «инноваџионный потенщиал», «оченка инновачионного потенциала предприятия». Проанализированы сильные и слабые стороны развития потенциала Украины. Рассмотрены и проанализированы методы осуществления оценки инновачионного потенциила предприятия, сильные и слабые стороны развития потенциала Украины. Автором предложен комплексный подход к оченке инновационного потенциала отечественного предприятия. Осуществлен сравнительный анализ нормативно правовых особенностей государственной регуляции трансфера технологий в Украине и США. Обнаружень преимущества и недостатки законодательной базы США в сфере передачи технологий. Проанализированы современные тенденции международного трансфера технологий, особенности отечественных законодательных актов, относительно исследований и разработок и инновачионной деятельности. Выделень проблемы институционного обеспечения передачи технологий в Украине. Сформулировань рекомендации относительно совершенствования отечественной законодательной базы в сфере трансфера технологий.

Ключевые слова: инновации; инновационный потенциал предприятия; трансфер технологий. 
The article considers the nature of the concepts of "innovation potential", "estimate innovation potential of the company." The strong and weak sides of development of potential of Ukraine are analysed. Considered and analysed methods of estimation of innovative potential companies, strengths and weaknesses of potential Ukraine. An integrated approach to assessing innovation capacity of enterprises. The made a comparative analysis of normatively legal features of the governmental control of the transfer of technologies in Ukraine and the USA. The advantages and disadvantages of the legislative base of the USA in the field of transmission of technologies are found out. The modern tendencies of the international transfer of technologies, the features of Ukrainian legislative acts, are analysed in relation to the researches and developments and the innovative activity. The problems of the institutional providing of the transmission of technologies are selected in Ukraine. The recommendations to perfect the Ukrainian legislative base in the field of transfer of technologies are formulated.

Key words: innovation, innovation potential of enterprises, transfer of technologies.

Вступ. В сучасних умовах функціонування світової економічної системи, розвитку науково-технічного прогресу більшість вітчизняних підприємств зіштовхуються з проблемою утримання своєї позиції на ринку. Відповідно до цього, кожне підприємство має здійснювати підприємницьку діяльність використовуючи власний інноваційній потенціал. В умовах подолання економічної кризи трансфер технологій України має великий потенціал на світовому ринку, однак де-факто він займає незначне місце серед інших країн за рівнем науково технічних досягнень.

Питанням формування та оцінки інноваційного потенціалу підприємства присвятили праці такі науковці: Коваль, І.Б. Маркович, Я.Г. Ільченко та Н.С. Краснокутська, які визначили необхідність в оцінці інноваційного потенціалу, однак не запропонували ефективної методики визначення інноваційного потенціалу на сучасному підприємстві. Однак, особливої уваги заслуговує потреба у формуванні комплексного методу оцінки інноваційного потенціалу підприємства.

Проблематика розвитку трансферу технологій висвітлена в наукових працях вітчизняних та зарубіжних вчених, зокрема: Капіци Ю.М. [1], Рудченко І. [2], Лукши О. [3], Федулової Л. та інших. Слід відзначити, що невирішеними залишаються питання удосконалення законодавства України щодо передачі технологій, та формування ефективної системи державного регулювання процесу трансферу технологій 3 урахуванням зарубіжного досвіду.

В сучасних умовах функціонування світової економічної системи трансфер технологій сприяє появі додаткових можливостей для економічного розвитку України і визначає перспективи створення ефективної системи комерціалізації технологій. В умовах подолання економічної кризи, формування інноваційного потенціалу та ефективне впровадження нововведень відкривають нові можливості перед підприємством і сприяють його інноваційному розвитку, що і зумовлює актуальність даної теми. 
Постановка завдання. Метою статті є аналіз існуючих методів оцінки інноваційного потенціалу та визначення найбільш ефективного, розвиток інноваційного потенціалу на основі трансферу технологій. Стаття присвячена розв'язанню наступних задач:

- проаналізувати існуючі методи оцінки інноваційного потенціалу;

- створити комплексний метод оцінки, який би міг відображати всі можливості підприємства;

- визначити позитивні та негативні сторони зарубіжної законодавчої бази у сфері передачі технологій;

- надати пропозиції 3 приводу удосконалення деяких положень вітчизняного законодавства враховуючи зарубіжний досвід.

Методологія. В процесі написання статті використані наступні методи дослідження: метод синтезу (для поєднання системного та процесного підходів до управління інноваційним потенціалом 3 метою створення комплексного підходу); метод порівняння (для аналізу особливостей вітчизняної та зарубіжної бази у сфері трансферу технологій); систематизації (для розроблення рекомендацій та пропозицій щодо вдосконалення вітчизняної законодавчої бази у сфері передачі технологій).

Результати дослідження. Трансфер технологій виступає інструментом розвитку інноваційного потенціалу за допомогою якого можна виокремити проблеми інституційного забезпечення передачі технологій в Україні.

Перехід суб'єктів господарювання на інноваційний шлях розвитку можливий лише за умови формування та реалізації інноваційного потенціалу, як основи цього розвитку.

За даними рейтингу Global Innovation Index 2013 року, над яким працюють фахівці Корнельського університету, бізнес-школи INSEAD та Всесвітньої організації інтелектуальної власності WIPO, інноваційний потенціал України зайняв 71-ше місце з поміж 142 країн Світу, отримавши 35,8 балів, за шкалою від 0 до 100. Аналізуючи сильні і слабкі сторони розвитку потенціалу України Global Innovation Index виділяє наступне (див. табл. 1) [4].

Таблиця 1

Сильні та слабкі сторони розвитку потенціалу України згідно Global Innovation Index

\begin{tabular}{|c|l|l|}
\hline $\begin{array}{l}\text { № } \\
\text { п/п }\end{array}$ & \multicolumn{1}{|c|}{ Сильні сторони } & \multicolumn{1}{|c|}{ Слабкі сторони } \\
\hline 1 & $\begin{array}{l}\text { Велика кількість заявок резидентів на створення } \\
\text { винаходів, корисних моделей }\end{array}$ & $\begin{array}{l}\text { Інформаційно-комунікаційні } \\
\text { технології }\end{array}$ \\
\hline 2 & Витрати на освіту & $\begin{array}{l}\text { Створення організаційних та } \\
\text { бізнес моделей }\end{array}$ \\
\hline 3 & Темпи зростання ВВП на одного зайнятого & $\begin{array}{l}\text { Інтенсивність місцевої } \\
\text { конкуренції }\end{array}$ \\
\hline
\end{tabular}


\begin{tabular}{l|l|l}
4 & Національна програма використання патентів & Ринкова капіталізація
\end{tabular}

Складено автором на основі [4]

Існує багато методичних підходів до управління інноваційним потенціалом. Розглянемо найбільш поширені 3 них, а саме системний та процесний підходи.

Суть системного підходу полягає в тому, що в основі будь-якої системи лежить сукупність взаємопов'язаних елементів яка має вхід, вихід, зв'язок 3 зовнішнім середовищем і зворотнім зв'язком.

За процесним підходом організація управління полягає не у контролі за виконавцями, діями та технологією виконання, а у відслідковуванні результатів їх функціонування.

На сучасному етапі управління інноваційним потенціалом підприємства доцільно розглядати комплексний підхід управління. Він полягає у поєднанні основних методик системного i процесного підходів. Особливості комплексного підходу наведені у табл. 2.

Таблиця 2

Особливості комплексного підходу до управління інноваційним потенціалом

\begin{tabular}{|c|c|}
\hline Характе & Зміст \\
\hline $\begin{array}{c}\text { Особливість } \\
\text { взаємодії елементів } \\
\text { всередині системи }\end{array}$ & $\begin{array}{l}\text { Елементи системи управління інноваційним потенціалом } \\
\text { знаходяться в постійній взаємодії, взаємозв’язок яких } \\
\text { контролюється } 3 \text { метою уникнення появи можливих розбіжностей у } \\
\text { цілях окремих елементів }\end{array}$ \\
\hline $\begin{array}{r}\text { Opгa } \\
\text { eко } \\
\text { M }\end{array}$ & $\begin{array}{l}\text { Особливість цього механізму полягає у забезпеченні управління } \\
\text { потенціалом, основними складовими якого є: цілі, принципи та } \\
\text { методики управління }\end{array}$ \\
\hline $\begin{array}{r}\text { Цілі } \\
\text { іннс } \\
\text { nот }\end{array}$ & $\begin{array}{l}\text { Забезпечення підприємства постійним інноваційним розвитком, } \\
\text { який полягає у ефективному функціонуванні підприємства, яке } \\
\text { можливе при змінному зовнішньому середовищі }\end{array}$ \\
\hline $\begin{array}{l}\text { Принциипи } \\
\text { управління } \\
\text { інноваційним } \\
\text { потенціалом }\end{array}$ & $\begin{array}{l}\text { Управління інноваційним потенціалом базується на принципах: } \\
\text { ефективності, збалансованості, результативності, адаптивності, } \\
\text { безперервності }\end{array}$ \\
\hline
\end{tabular}

Складено автором

На вітчизняних підприємствах існує проблема створення єдиного математичного механізму оцінки інноваційного потенціалу підприємства, що б сприяло його оцінці та порівнянню потенціалів різних підприємств.

Визначення інноваційного потенціалу як комплексного потенціалу діяльності підприємства доцільно сформувати у систему яка включає: ринковий, кадровий, фінансовий та інформаційний потенціали [5]. 
1) Ринковий потенціал - сукупність можливостей підприємства як всередині компанії, так і іï зовнішніх перспектив створити необхідних продукт для споживача для отримання максимальної вигоди.

2) Кадровий потенціал - це загальна характеристика персоналу як виду ресурсів, що визначає виконання необхідних функцій, що забезпечує дефективність функціонування підприємства в цілому.

3) Фінансовий потенціал - обсяг власних, позичених та залучених фінансових ресурсів підприємства, що сприяють досягненню стратегічних цілей підприємства. Система показників фінансового потенціалу підприємства включає: коефіцієнт загальної рентабельності підприємства, коефіцієнт рентабельності власного капіталу, коефіцієнт прибутковості реалізації, коефіцієнт прибутковості операційної діяльності, коефіцієнт ділової активності.

4) Інформаційний потенціал - найважливіший аспект загального соціокультурного потенціалу, що показує ступінь інформованості підприємства та уміння аналізувати і використовувати існуючу інформацію.

Найбільш вживаним для підприємств України є метод експертних оцінок. Він має найширше практичне застосування. Для проведення методу експертних оцінок необхідно залучити 5 - 10 експертів. Експертами повинні бути як представники підприємства (управлінська ланка, інженери, технологи), так і експерти ззовні (залучені спеціалісти з аналізованих питань).

За оцінками експертів можна розраховувати середньозважені значення оцінок експертів $\left(x_{i} \beta_{i}\right)$ по кожному показнику за використанням формули математичної статистики:

$$
x_{i} \beta_{i}=\frac{1}{n} \sum_{j=1}^{n} x_{i j} \beta_{i j}
$$

де $x_{i j}$ - бал, виставлений $j$-м експертом за $i$-м показником;

$B_{i j}$ - коефіцієнт вагомості, виставлений $j$-м експертом за $i$-м показником;

$\mathrm{n}$ - кількість експертів.

Для діагностики інноваційного потенціалу використовують анкету в якій за чотирибальною шкалою визначають задоволеність або незадоволеність інноваційним потенціалом компанії та результати ранжують за рівнем вагомості [6].

Запропоновані методи через динамічний характер інноваційного розвитку підприємства мають свої недоліки: вузькість оцінки потенціалу, що унеможливлює об’єктивність розрахунку інноваційного потенціалу підприємства. Таким чином, для найбільш завершеної оцінки інноваційного потенціалу необхідний комплексний підхід, який полягає у сумарній оцінці інноваційного потенціалу 3 різних сторін. Він включає поєднання аналізу загальноінноваційних показників (показники фінансування та 
результативності НДДКР, показники технологічного лідерства, показники ефективності інноваційної діяльності, показники ефективності взаємодії 3 зовнішніми джерелами розроблення інновацій) та аналізу потенціалів діяльності підприємства, що корегується за рахунок оцінки експертів (рисунок).

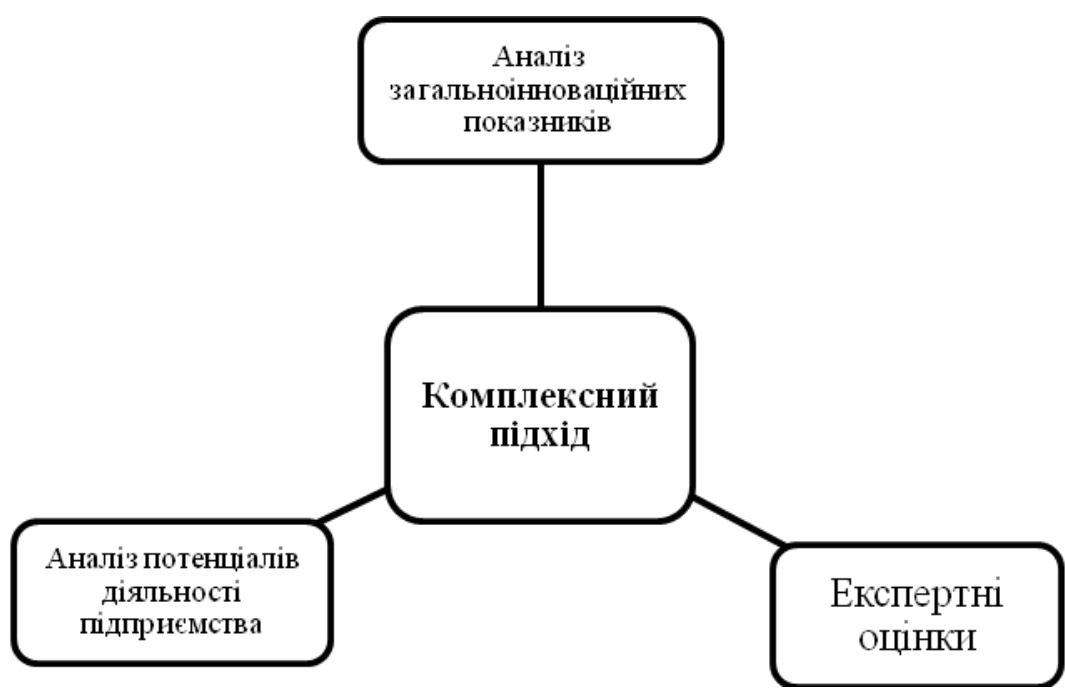

Рисунок. Комплексний підхід оцінки інноваційного потенціалу Складено автором на основі [6]

Слід зазначити, що найбільш об'єктивну оцінку інноваційному потенціалу підприємства дає комплексний аналіз за усіма вище запропонованими методиками. Його використання дозволить уникнути розбіжностей, неточностей та суб’єктивізму.

Трансфер технологій $є$ ключовим фактором економічного розвитку кожної країни та розвитку інноваційного потенціалу підприємства зокрема. Особливої актуальності набувають питання забезпечення високих стандартів захисту прав інтелектуальної власності, активізації діяльності у сфері трансферу технологій в процесі формування інноваційного потенціалу.

3 огляду на вище викладене, доцільно проаналізувати вітчизняний та закордонний досвід щодо залучення іноземних технологічних інвестицій та передачі технологій.

Впровадження ефективного механізму трансферу технологій в Україні є основою активізації інноваційної діяльності, формування інноваційного потенціалу вітчизняних підприємств та фактором розвитку національної інноваційної системи.

Розглянемо нормативно-правові акти США, що регулюють передачу технологій. Зокрема, зупинимося на перевагах та недоліках (див. табл.3). 
Таблиця 3

Переваги та недоліки законодавчої бази США у сфері трансферу технологій

\begin{tabular}{|c|c|c|}
\hline Законодавча база США & Переваги & Недоліки \\
\hline $\begin{array}{l}\text { Закон Стівенсона Уайдлера } \\
\text { про технологічні } \\
\text { від } 1980 \text { р. }\end{array}$ & 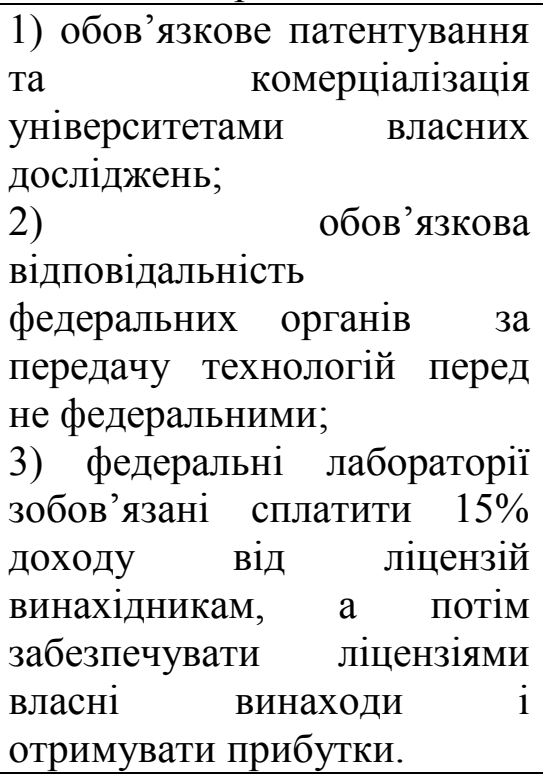 & $\begin{array}{l}\text { 1) Недосконалість механізму } \\
\text { патентування та } \\
\text { ліцензування; } \\
\text { 2) неможливість регулювати } \\
\text { проектно-дослідницьку } \\
\text { діяльність НАСА та } \\
\text { міністерства енергетики. }\end{array}$ \\
\hline $\begin{array}{l}\text { Закон Бей Доула (Bayh- Dole } \\
\text { Act), від } 1980 \text { р. }\end{array}$ & $\begin{array}{l}\text { 1) Передача інтелектуальної } \\
\text { власності, створеної за } \\
\text { участю держави, } \\
\text { університетам; } \\
\text { 2) комерціалізація винаходів } \\
\text { та забезпечення ї } \\
\text { ліцензіями; } \\
\text { 3) одержання виконавцями } \\
\text { НдР прав інтелектуальної } \\
\text { власності щодо інформації, } \\
\text { яка не може бути } \\
\text { запатентована (зокрема } \\
\text { комерційної таємниці); } \\
\text { 4) забезпечення роботи } \\
\text { спеціальних судів, } \\
\text { спрямованих } \\
\text { урегулювання спорів у сфері } \\
\text { передачі технологій. }\end{array}$ & $\begin{array}{lrr}\begin{array}{l}\text { Неможливість } \\
\text { держави }\end{array} & \begin{array}{r}\text { боку } \\
\text { відреагувати }\end{array} \text { на } \\
\begin{array}{l}\text { зменшеннй } \\
\text { конке }\end{array} \\
\begin{array}{l}\text { конкурентоспроможності на } \\
\text { світовому ринку }\end{array}\end{array}$ \\
\hline $\begin{array}{l}\text { Закон «Про торгові марки» } \\
\text { від } 1984 \text { р. }\end{array}$ & $\begin{array}{lc}\text { 1) розширення } & \text { положення } \\
\text { щодо передачі технологій на } \\
\text { федеральні } \\
\text { якими вабораторії, } \\
\text { управляють не } \\
\text { суб'єкти; } \\
\text { 2) кередеральнни } \\
\text { лабораторій } \\
\text { одержувати федеральних } \\
\text { патенти на нові технології та }\end{array}$ & $\begin{array}{l}\text { Розбіжність деяких положень } \\
\text { цього закону із іншими } \\
\text { нормативно-правовими } \\
\text { актами }\end{array}$ \\
\hline
\end{tabular}




\section{Складено на основі [7]}

отримувати прибутки від ліцензій для просування на ринку інновацій.

Виходячи 3 вище викладеного, можна зробити висновок, що в США здійснюється значна підтримка з боку держави (фінансова, організаційна та податкова) у сфері передачі технологій.

Розглянемо деякі законодавчі акти у сфері трансферу технологій в Україні:

1) Закон України «Про інноваційну діяльність» потребує доопрацювань, оскільки неправильно трактує представників інноваційної інфраструктури, відносячи їх до інноваційних підприємств. В новій редакції Закону є норма щодо можливості організації офісів по передачі технологій, що важливо для організації процесу трансферу технологій.

2) Закон України «Про наукову і науково-технічну діяльність» внаслідок відсутності податкових та фінансових важелів державного регулювання в інноваційній та науковій діяльності є неефективним.

3) Закон України «Про державне регулювання діяльності у сфері трансферу технологій» $є$ частково ефективним, зважаючи на те, що положення закону щодо цільового субсидіювання передачі технологій не виконуються i не мають податкових пільг $[8,9,10]$.

Перша редакція цього Закону суперечила нормам TRIPS (угода про торговельні аспекти прав інтелектуальної власності прийнятої в 1994 р.), а також вже існуючому вітчизняному законодавству, тому більшість положень було змінено. Друга редакція закону, прийнятого 14 вересня 2006 року передбачала впровадження механізму пільг щодо передачі технологій, однак на практиці він мав лише декларативний характер і не здійснював контролю за іноземними технологіями та їх використанням у пріоритетних сферах економіки.

Остання редакція цього закону від 2 жовтня 2012 р. має певні відмінності, зокрема: майнові права на розроблені технології за рахунок державного фінансування будуть належати самим розробникам; організація, що розробила нову технологію зможе використовувати кошти, одержані від передачі технологій на власну інноваційну діяльність; експертиза об'єктів інтелектуальної власності, придбаних за допомогою бюджетних коштів, здійснюватиметься з урахуванням економічної доцільності та корисності для України.

Як підсумок можна згрупувати наступні пропозиції щодо удосконалення законодавчої бази України у сфері трансферу технологій:

1) в Законі України «Про інноваційну діяльність» необхідно ввести положення щодо використання несплачених сум податків на науковотехнічну діяльність, розвиток науково-дослідної бази; впровадження 
механізму стимулювання державою інноваційної діяльності, елементи якого пов'язані з інноваційними пріоритетами;

2) в Законі України «Про наукову і науково-технічну діяльність» слід: визначити порядок розподілу майнових прав інтелектуальної власності на інноваційний продукт, що фінансуються державою; виплати винагороди винахіднику об'єктів права інтелектуальної власності (ОПІВ); залишити майнові права за організацією-виконавцем НДДКР; розробити реальні механізми комерціалізації суб'єктами майнових прав ОПІВ, що створені за рахунок коштів 3 держбюджету та закріпити різноманітні податкові стимули щодо такої комерціалізації;

3) в Законі України «Про державне регулювання діяльності в трансфері технологій» необхідно сформувати механізм партнерських стосунків між державою та приватним сектором у сфері трансферу технологій.

В Україні відсутня єдина національна система трансферу технологій, стратегія економічного розвитку країни, належна патентно-ліцензійна політика, координація науково-технічної сфери (через передачу функцій Держкомітету України з питань науки та інтелектуальної власності МОН), присутній низький рівень інноваційної активності.

Необхідно зазначити, що процес взаємодії трансферу технологій в контексті управління інноваційним потенціалом дозволяє уникнути настання інноваційної кризи, створює нові можливості для розвитку інноваційного потенціалу.

Висновки. Отже, після аналізу запропонованих методів оцінки інноваційного потенціалу було визначено найбільш ефективний, комплексний метод, який базується на поєднанні трьох методів оцінки та розкриває всі аспекти інноваційного розвитку підприємства.

Теоретичне та практичне значення результатів дослідження містить методика оцінки інноваційного потенціалу яка допоможе полегшити управління інноваційного діяльністю підприємств. Крім того, вітчизняне законодавство у сфері передачі технологій перебуває на стадії розвитку, тому доцільно враховувати зарубіжний досвід, вносити зміни у вже існуючі нормативно-правові акти i таким чином удосконалювати правове регулювання цих відносин.

Проведене дослідження доводить, що нормативно правова база України в сфері трансферу технологій має стати гарантією прозорості, надійності та тривалості стосунків між державою, інвесторами та науковим сектором.

Перспективою подальших наукових розробок може бути розширення дослідження вищезазначених напрацювань 3 урахуванням міжнародного досвіду у сфері інновацій та оцінки інноваційного потенціалу. Результати дослідження формування дієвого механізму державного регулювання 
трансферу технологій може використовуватись в діяльності вітчизняних підприємств, яка забезпечить ефективне використання інноваційного потенціалу держави.

\section{Література:}

1. Капіца Ю.М. Міжнародно-правове регулювання у сфері трансферу технологій та національні пріоритети: проблеми співвідношення / Ю.М. Капіца // Міжнародне приватне право: розвиток, порівняльний аспект, гармонізація Режим доступу: http://ndippp.gov.ua/Schorichnuk/Kapitsa.pdf. - Назва з екрану.

2. Рудченко І. Трансферт технологій як елемент інноваційної інфраструктури / I. Рудченко // Теорія і практика інтелектуальної власності.-2008. - №4. - С.61-68.

3. Лукша О. Как работать с сетями трансфера технологий: практическое пособие [Електронний ресурс] / О.Лукша, Г.Пильнов, О.Тарасова, А.Яновский; проект EuropeAid «Наука и коммерциализация технологий». - 2006. - 140 с. - [Електронний pecypc]. - Режим доступу: <http://rasstc.ru/goods/2>. - Назва з екрану.

4. Офіційний сайт «Global Innovation Index 2013: The Local Dynamics of Innovation» [Електронний pecypc]. <http://www.globalinnovationindex.org/content.aspx?page=interactive-SW>

5. Дослідження систем управління: Навчальний посібник / За редакцією Е.М.Коротков. - Київ: «Дека», 2000. - 336с. - ISBN 589645-014-1.

6. Гук О.В. Особливості оцінки інноваційного потенціалу підприємства / О.В. Гук, Н.Ю.Рощина // Економічний простір: Збірник наукових праць - № 75 . Дніпропетровськ: ПДАБА, 2013. - С. 181-190.

7. Лукша О. Как работать с сетями трансфера технологий: практическое пособие [Електронний ресурс] / О.Лукша, Г.Пильнов, О.Тарасова, А.Яновский; проект EuropeAid «Наука и коммерциализация технологий». - 2006. - 140 с. - [Електронний pecypc]. - Режим доступу: <http://rasstc.ru/goods/2>. - Назва з екрану.

8. Закон України «Про інноваційну діяльність». Відомості Верховної Ради України (BBP), 2002, N 36, ст.266 [Електронний ресурс]. - Режим доступу: http://zakon4.rada.gov.ua/laws/show/40-15.

9. Закон України «Про наукову і науково-технічну діяльність». Відомості Верховної Ради України (ВВР), 2000, N 28. - ст.22. - [Електронний ресурс]. - Режим доступу: http://zakon4.rada.gov.ua/laws/show/1646-14.

10. Закон України «Про державне регулювання діяльності в трансфері технологій». Відомості Верховної Ради України (ВВР), 2006, № 45, ст.434. [Електронний ресурс]. Режим доступу: http://zakon4.rada.gov.ua/laws/show/143-16 